\title{
Comentário a \\ “O CÉu dos Sábios: O SOl de Platão a partir das estrelas de Nietzsche”: A respeito do Sol de Platão NO CÉU ESTRELADO NIETZSCHIANO
}

Rosana Suarez ${ }^{1}$

Referência do texto comentado: SABATINI, Marco. O céu dos sábios: o sol de Platão a partir das estrelas de Nietzsche. Trans/Form/Açáo: revista de filosofia da Unesp, v. 44, n. 2, 2021, p. $233-250$.

Nietzsche pode fazê-lo; nós, melhor que não o façamos. Fazer o quê? Nietzsche foi hiperbólico. Fez caricaturas de filósofos célebres. Formulou cisóes epocais inusitadas, do ponto de vista da historiografia tradicional. Tudo isso para magnificar o que em grande parte só ele via, mas nos deu a ver; e disso nós nos beneficiamos até hoje. Nesse sentido, os perfis filosóficos magistralmente criados por Nietzsche não pertencem a "pessoas": "Nunca ataco pessoas; sirvome da pessoa como de uma forte lente de aumento com que se pode tornar visível um estado de emergência geral, porém dissimulado, pouco palpável." (NIETZSCHE, 1985, "O caso Wagner").

Devemos imitar Nietzsche, insisto e repito, sermos tão hiperbólicos quanto ele? Podemos "cancelar" Platão, por assim dizer, na medida em que Nietzsche o escolheu como o seu adversário de maior porte? Decerto que não.

${ }_{1}^{1}$ Professora associada da Faculdade de Filosofia da Universidade Federal do Estado do Rio de Janeiro (UNIRIO), Rio de Janeiro, RJ - Brasil. (D) https://orcid.org/0000-0003-1877-6299. E-mail: rosanasrz@gmail.com.

https://doi.org/10.1590/0101-3173.2021.v44n2.18.p251

\section{(i)}


Na década de 1980, entre outras, grassava o antiplatonismo junto aos aficionados de Nietzsche. Mais de uma vez - embora eu me considerasse "nietzschiana" -, assisti constrangida a palestrantes achincalharem o pensador grego aluno de Sócrates, como se fosse um vizinho de péssima fama no bairro. Faziam-no e ainda o fazem igualmente com Descartes, por exemplo. Longe de nós a sina de nos inscrevermos em "times" filosóficos, porém. Deixemos o "Futebol dos Filósofos" ao talento do grupo de comediantes ingleses Monty Python!

$\mathrm{O}$ acerto de contas de Nietzsche com Platão é o cerne do instigante "O céu dos sábios: o Sol de Platão a partir das estrelas de Nietzsche”, de Marco Sabatini. O próprio autor o reconhece:

Como sabemos, um dos pontos mais fundamentais e polêmicos na filosofia de Nietzsche reside em sua crítica a Platão. De acordo com o filósofo, Platão lançou e consolidou as bases do cristianismo muito antes dos pensadores medievais. Por meio de sua metafísica, o platonismo teria realizado uma verdadeira apologia a um plano ideal e radicalmente superior ao nosso mundo sensível (SABATINI, 2021, p. 236).

Abordar a crítica do platonismo - tema incontornável, como vemos, na filosofia nietzschiana - é difícil e perigoso. A depender de como isso é feito, temos um calcanhar de Aquiles. Da maneira como Sabatini o faz, com vieses, tons e meio tons, somos poupados da maior parte das armadilhas a que antes me referia.

Platão aos olhos de Nietzsche; Platáo aos nossos olhos, através do prisma nietzschiano; a nossa visão a respeito de Nietzsche: são planos sobre planos, perspectivas em perspectivas - para usar uma palavra de relevância nietzschiana. Assim como o "Sol" platônico poder ser dito um "grande olho" a nos mirar e inquirir - mais do que uma ideia que intelectualizamos; assim também, o relento estrelado nietzschiano pode nos ilustrar e desnudar.

Retomo em caráter crítico alguns pontos, para refletir no excelente artigo de Marco Sabatini, de modo a continuarmos a ruminar a importante investigação aí proposta. Por exemplo, pergunto eu: a sinonímia nietzschiana entre cristianismo e platonismo seria suficiente, hoje, enquanto pedra de toque interpretativa? Isso dado o surgimento ou ressurgimento de cultos tão excêntricos, que, ao se dizerem cristãos, buscam produzir uma regressão dramática para aquém do próprio surgimento da filosofia clássica, platônica; e, mesmo, da filosofia dos pré-socráticos? 
Vivemos numa época em que a leitura dos jornais nos permite identificar tantas falácias que, mesmo considerada "linear", a disciplina da Lógica aristotélica parece ressurgir com um grande potencial crítico! De forma convergente, pergunto: seria possível, hoje, prescindirmos do olhar de Platão, por exemplo, no Górgias, cujo desvelamento da "ética" atinente à retórica sofística parece talhada para descrever o caráter de certos líderes mundiais com acesso amplo às mídias digitais? Numa época quando o irracionalismo faz escola, não teria a filosofia clássica racionalista algo a nos ensinar, nesta outra volta do parafuso? Isso a despeito da crítica incontornável de Nietzsche ao platonismo, cujas várias nuanças, indubitavelmente, Marco não nos deixa de apresentar e detalhar?

Enquanto proponho essas questóes, em forma de provocaçóes, valorizo imensamente o realce dado por Sabatini às formulaçôes nas quais pondera, com Nietzsche, que a luminosidade do Sol da razão no céu ocidental obscureceu tanto os belos corpos celestes a evoluírem a seu lado que, talvez, não os vejamos jamais. Desconheço melhor alegoria, aliás, para o atualmente chamado "epistemicidio", conceito cunhado pelo pensador português Boaventura de Souza Santos e desenvolvido, entre nós, pelas brasileiras Sueli Carneiro e Djamila Ribeiro. Nietzsche já propusera o conceito desde o seu primeiro livro, $O$ nascimento da tragédia, obra na qual estabelece, com originalidade e acuidade, o golpe fatal desfechado na encruzilhada em que se separam tragicamente o saber racional, socrático-platônico, do mito-poético.

São essas as indagaçóes que faço, leitora que sou aficionada da filosofia e das suas múltiplas versóes e potencialidades. Agradeço desde já quaisquer consideraçóes que o colega Marco Sabatini quiser fazer a respeito.

\section{REFERÊNCIAS}

CARNEIRO, Sueli. Escritos de uma vida. Belo Horizonte: Letramento, 2018.

NIETZSCHE, Friedrich. Ecce Homo, como alguém se torna o que é. Tradução de Paulo César de Souza. São Paulo: Max Limonad, 1985.

NIETZSCHE, Friedrich. O nascimento da Tragédia. Tradução de J. Guinsburg. São Paulo: Companhia de Bolso, 2007.

RIBEIRO, Djamila. Pequeno manual antirracista. São Paulo: Companhia das Letras, 2019. 
SABATINI, Marco. O céu dos sábios: o sol de Platão a partir das estrelas de Nietzsche. Trans/Form/Açáo: revista de filosofia da Unesp, v. 44, n. 2, 2021, p. 233 - 250.

SOUSA, Boaventura de Santos. O fim do império cognitivo: a afirmação das epistemologias do Sul. Belo Horizonte: Autêntica, 2019.

SUAREZ, Rosana. Nietzsche comediante - a filosofia na ótica irreverente de Nietzsche. Rio de Janeiro: 7Letras, 2007. 